All issues of this journal are alternatively stored and archived by: the National Library of Thailand, Russian E-library and Index Copernicus library of journals, Poland

\title{
SHORT-TERM DEBT AND FIRMS' EARNINGS MANAGEMENT CHOICES: THE CASE OF VIETNAM
}

\author{
Vang Dang Quang \\ HCMC University of Technology and Education, Ho Chi Minh City, Vietnam \\ Hung Tran Van \\ Vietnam National University of Forestry, Southern Campus, Dong Nai Province, Vietnam
}

The primary purpose of this research is to explore the link between short-term debt and firms' earnings management choices. It focuses on understanding how and when short-term debt will improve or reduce the earnings management activity of companies. Our proxy for real earnings management is based on the measure developed by (Roychowdhury, 2006). Using a sample of listed firms in the period of 2009-2018 in Vietnam, the study determines an important positive correlation between short-term debt and real activities manipulation. Our results further show that firms having lower levels of short-term debt tend to use real earnings management activities, but those that have higher levels of short-term debt are prone to use accrual-based earnings management method rather than altering real activities, inducing an inverted $U$-shaped relationship between short-term debt and real earnings management.

Keywords: short-term debt; real earnings management; accrual-based earnings management

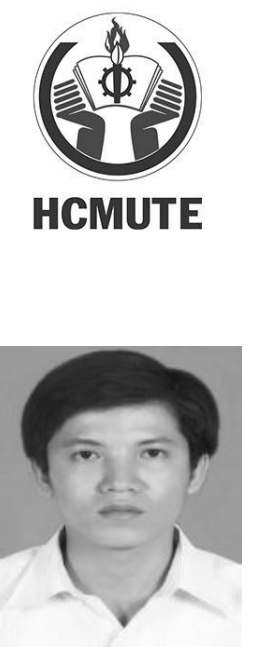

\author{
Vang Dang Quang \\ Researcher at HCMC University of Technology and Education, Ho Chi Minh City, \\ Vietnam. \\ Research interests: education services, education technologies, finance and banking, \\ customers behavior \\ E-mail: hungtv@vnuf2.edu.vn
}

\section{Hung Tran Van}

$\mathrm{PhD}$, Lecturer, Faculty of Economics, Vietnam National University of Forestry, Southern Campus, Dong Nai Province, Viet Nam

Research interests: markets of agricultural products, SMEs functioning and government support, ecological economics, environmental issues of economic development, financial management.

E-mail: hungtv@vnuf2.edu.vn 


\section{SHORT-TERM DEBT AND FIRMS' EARNINGS}

\section{Introduction}

The influence of short-term debt on firms' earnings management choices has been already illustrated by (for example, Gupta et al., 2008; Fung \& Goodwin, 2013; Fields et al., 2018). Previous research, however, has been primarily focused on accrual-based earnings management (AEM). This paper complements the existing literature in several ways. First, by analyzing the effect of short-term debt on real earnings management (REM) practices, this research expands the results obtained in previous studies. In prior literature, the focus has mostly been limited to the AEM as a proxy for earnings management.

Secondly, this paper attempts to explore the non-linear link between REM and shortterm debt. Importantly, the author investigates this link given the managerial discretion in choosing AEM and REM at low and high short-term debt levels. The findings will extend the results obtained by Zang (2012) which has found that REM and AEM are used by managers as replacements for the management of earnings, and works that suggest debt, especially short-term one, has a distinctive dual role in determining earnings quality (see, for example, Ghosh \& Moon (2010)). Last but certainly not least, this article considers the related issues in the context of Vietnamese stock market, an important frontier market in Asia recently. The evidence on the above linkages is quite scant in the case of this market specifically.

In our study, we use three proxies including the firm's abnormal production costs (REM1), abnormal discretionary expenditures (REM2), and an overall index combining both components respectively (REM3), all following (Roychowdhury, 2006). The study shows that there is a clear, positive link between short-term debt and REM in the sample of companies listed at Vietnamese stock market, 2009 to 2018. Our results further show that the firms with lower short-term debt tend to use REM, but those with higher one are prone to use AEM rather than altering real activities, inducing an inverted U-shaped relationship between short-time debting and REM.

The rest of this text is structured as follows. The background and hypotheses development are given in Section 2. Section 3 presents the study methodology and the data. The key findings and robustness measures are covered in Section 4. Section 5 summarizes with the conclusions and relevant consequences.

\section{Background and hypotheses development}

\section{Firms' earnings management choices}

The literature on earnings management has no single definition for its central category (El Diri, 2018). Most definitions explain the meaning of earnings management by emphasizing how managers manipulate their earnings.

There are two methods to manipulate earnings - real earnings management vs accrual-based earnings management. Roychowdhury (2006) discussed how managers choose between AEM and REM when they have the flexibility to engage in both. Zang (2012) documented a substitution effect between these two earnings management strategies. El Diri (2018) reviewed the literature on these two methods and showed that firms are likely to use a mix of them as a strategy to manipulate reported earnings. 


\section{Short-term debt and firms' earnings management choices}

As per previous research, short-term debt in general could provide monitoring benefits due to the agency-cost mitigating role (Myer, 1977; Ahn \& Choi, 2009). However, managers may manipulate corporate earnings for many motives, for example, as predicted by the financial distress hypothesis, short-term debt is linked favorably to earnings management (Fung \& Goodwin, 2013). The possible refinancing pressures induced by short-term debt adjustments and future loan funding are also a trigger for the positive connection between short-term indebtedness and earnings management (Fields et al., 2018; Brusenskaya et al., 2018). While two approaches are usually used to manipulate earnings, most of the previous studies choose AEM for firms' earnings management choices.

\section{Development of hypotheses}

From the financial distress perspective, to prevent the increase in liquidity risk, firms need to pay off short-term debt once it is due. Thus, short-term debt may incentivize firms to exploit their earnings. In other words, the more short-term debt, the stronger incentives for firms to manage their earnings. Real earnings management could help firms save cash, increase (temporary) cash flows from sales at higher discount rates, thus allowing firms to avoid financial distress and liquidity risk caused by short-term debt. Thus, our first hypothesis is formulated on the basis of these arguments as follows:

H1: Other things being equal, firms with a higher level of short-term debt have a higher degree of real earnings management.

At short-term debt being at lower levels, the pressure of financial distress and liquidity risk is lower, then firms may choose between REM and AEM at their discretion. AEM has its own costs and is more likely to be uncovered by experienced auditors and stakeholders, while managers can disguise REM as conventional and legitimate cost-cutting or salepromoting activities. However, at higher levels of short-term debt, when the risk of financial distress as well as liquidity risk have higher chances of occurrence, managerial choice of REM could easily signal about firm's weak financial health. Therefore, managers may be more inclined to resort to AEM instead of REM.

Therefore, we contend that firms tend to have high REM activities at lower levels of short-term debt, but as soon as short-term debt gets to higher levels, firms appear to have AEM, and are thus limiting their REM activities. Hence, our second hypothesis is formulated as follows:

H2: The connection between short-term debt and REM is reversed in U-fashion.

\section{Methodology and data}

\section{Methodology}

To test these two hypotheses above, we stem from Andhov et al. (2019), Roychowdhury (2006), Fung \& Goodwin (2013), Jančíková et al. (2016), Fields et al. (2018), Ghosh \& Moon (2010) and select the following models: 


\section{SHORT-TERM DEBT AND FIRMS' EARNINGS}

$$
\begin{aligned}
& \text { REM }_{\text {it }}=\beta_{0}+\beta_{1} \text { STD }_{i t}+\beta_{2} \text { AEM }_{\text {it }}+\beta_{3} \text { STD } * \text { AEM }_{\text {it }}+\text { Controls }_{i t}+\varepsilon_{i t} \text {, } \\
& \mathrm{REM}_{\mathrm{it}}=\beta_{0}+\beta_{1} \mathrm{STD}_{\mathrm{it}}+\beta_{2}\left(\mathrm{STD}_{\mathrm{it}}\right)^{2}+\beta_{3} \mathrm{AEM}_{\mathrm{it}}+\text { Controls }_{\mathrm{it}}+\varepsilon_{\mathrm{it}} \text {, }
\end{aligned}
$$

where:

REM is the dependent variable, that of real earnings management, using both three proxy include firm's abnormal production costs (REM1), abnormal discretionary expenditures (REM2), and an overall index combining both components (REM3), following (Roychowdhury, 2006).

STD is the focal independent variable, measured by Fung \& Goodwin's (2013) as the share of short-term debt against total assets.

AEM is also the key explanatory component which is calculated through discretionary accruals as in (Dechow \& Dichev, 2002; Popova et al., 2018)) while cash flow is modified as in (McNichols, 2002).

Controls are the vector of control variables drawn from prior literature. As a proxy for firms' size, growth opportunities, and financial health, we utilize the natural total assets logarithm (SIZE), the sale growth ratio (GROW), and the return on assets (ROA) respectively. We add the proportion of cash and equivalents to the overall assets (CASH) to monitor the possible correlation between cash holdings and earnings management. Moreover, we resort to the dummy variable (BIG4) to capture the effect of Big 4 auditors' monitoring on managers' opportunistic behavior. Finally, we include the dummy variables (IND4 and IND7) to control whether firms are in litigation-prone industries such as Technology and Energy (Huang \& Sun, 2017).

We further control for potential endogeneity caused by the two-way correlation between the dependent and the explanatory variables by lagging all the explanatory variables by one period.

\section{Descriptive statistics and correlation matrix}

In the period of 2009-2018, we have picked the non-financial companies listed at Vietnamese stock exchange. We then deselect financial (GIC codes 4010-4030) firms because they have different operational types and are subject to special regulation. We only choose leveraged firms for our sample because we intend to focus on the effect of short-term debt on REM.

The final sample has the maximum number of 626 firms and 5,150 firm-year observations. Tables 1 and 2 below show the descriptive statistics for the variables used in our analysis, and the correlation matrix.

From Table 1, 72.37\% of the total debt is short-term debt. This implies that Vietnamese listed firms have relatively high levels of short-term debt. On average, firms' return on assets (ROA) is $7.1 \%$, firms' growth rate is $24.27 \%$, and firms' cash-to-asset ratio is $14.57 \%$ in the period examined. About one-tenth of all studied firms hire well-known (Big Four affiliated) auditors. Technology firms account for $7.88 \%$ of the sample, while energy sector firms cover $3.03 \%$ of all the firms in our sample. 
Table 1 - Variables' descriptive statistics

(Source: Authors' own calculations)

\begin{tabular}{|c|c|c|c|c|c|}
\hline Variable & Obs & Mean & Std.Dev. & Min & Max \\
\hline REM1 & 4,466 & -0.0005 & 0.1607 & -0.8310 & 1.6820 \\
\hline REM2 & 5,146 & -0.0002 & 0.0937 & -2.0530 & 0.3270 \\
\hline REM3 & 4,466 & -0.0015 & 0.2232 & -1.4730 & 1.7280 \\
\hline STD & 4,371 & 0.7237 & 0.3195 & 0.0000 & 1.0000 \\
\hline AEM & 5,136 & -0.0002 & 0.1999 & -5.7420 & 2.1870 \\
\hline SIZE & 5,148 & 26.9868 & 1.4987 & 23.3304 & 32.2004 \\
\hline ROA & 5,119 & 0.0707 & 0.0846 & -0.7870 & 0.8390 \\
\hline GROW & 4,517 & 0.2427 & 2.3433 & -1.0000 & 127.4579 \\
\hline CASH & 5,148 & 0.1457 & 0.1542 & 0.0001 & 0.9743 \\
\hline BIG4 & 4,990 & 0.1100 & 0.3129 & 0.0000 & 1.0000 \\
\hline IND4 & 5,150 & 0.0788 & 0.2695 & 0.0000 & 1.0000 \\
\hline IND7 & 5,150 & 0.0303 & 0.1714 & 0.0000 & 1.0000 \\
\hline
\end{tabular}

Table 2 - Correlation matrix of the variables

(Source: Authors' own calculations)

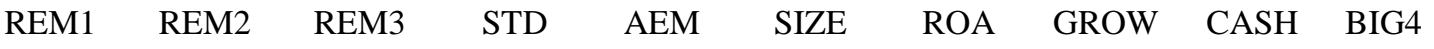

\begin{tabular}{ccccccccccc}
\hline REM1 & 1.000 & & & & & & & & \\
REM2 & $0.566^{*}$ & 1.000 & & & & & & & \\
REM3 & $0.945^{*}$ & $0.805^{*}$ & 1.000 & & & & & & \\
STD & $0.055^{*}$ & $-0.009 *$ & $0.034^{*}$ & 1.000 & & & & & \\
AEM & $0.185^{*}$ & $0.080^{*}$ & $0.155^{*}$ & 0.021 & 1.000 & & & & \\
SIZE & $0.054^{*}$ & $0.035^{*}$ & $0.057^{*}$ & $-0.252^{*}$ & $0.056^{*}$ & 1.000 & & & \\
ROA & $-0.474^{*}$ & $-0.176^{*}$ & $-0.412^{*}$ & $-0.034^{*}$ & $0.084^{*}$ & $-0.044^{*}$ & 1.000 & & \\
GROW & $-0.001^{*}$ & $-0.051^{*}$ & -0.021 & 0.004 & 0.011 & 0.025 & $0.068 *$ & 1.000 & \\
CASH & $-0.253^{*}$ & $-0.123^{*}$ & $-0.238^{*}$ & 0.015 & $-0.041^{*}$ & $-0.089 *$ & $0.401 *$ & -0.025 & 1.000 \\
BIG4 & $-0.037^{*}$ & $-0.059^{*}$ & $-0.043^{*}$ & -0.025 & -0.012 & $0.330^{*}$ & $0.042^{*}$ & -0.012 & 0.073 & 1.000 \\
\hline
\end{tabular}




\section{SHORT-TERM DEBT AND FIRMS' EARNINGS}

From Table 2, all three proxies for REM have positive correlations with each other, and also have a positive sign with AEM. This suggests that firms use these methods of REM and mix them with AEM in a rather flexible way. Besides, all three measures for REM have significant correlations with STD. This indicates that short-term debt may have some connections with real earnings management. Interestingly, STD has positive correlations with both REM1 and REM3, but a negative correlation with REM2. It seems that short-term debt only affects REM when it is measured by REM1.

\section{Results and discussion}

\section{Main findings}

Table 3 shows the effect on REM of short-term debt. In Table 3, Columns 1-3 present the regression results for three proxies of REM, namely, abnormal costs of production (REM1), abnormal discretionary expenditures (REM2), and an overall measure combining both components (REM3) without controlling for endogeneity. Finally, columns 4-6 present the results after controlling for endogeneity (by lagging all the independent variables by one period).

From Table 3, the coefficients of STD in Columns 1, 3, and 4 are significantly positive. Therefore, in line with our initial hypothesis H1, it is likely that firms with higher debt levels have higher degrees of REM. The coefficients of STD_AEM on Columns 1, 3, 4, and 6 are also significantly positive, suggesting that in general, short-term debt tends to induce both AEM and REM. Interestingly, the effect is documented when using proxy REM1 for real earnings management, consistent with the correlation matrix results.

Table 4 presents our first test of the inverted U-shaped relationship between short-term debt and REM. Columns 1-3 again show the results before endogenous regulation, and columns 4-6 replicate the results once the control function has been applied.

From Table 4, the coefficients of STD tend to be significantly positive, while STD2 is negatively related to REM. This finding supports our initial assumption that the relationship between short-term debt and REM is nonlinear (inverted U-shaped) as stated in $\mathrm{H} 2$. That is, at short-term debt low levels, firms are more likely to conduct REM activities. Conversely, at higher levels of short-term debt, firms have a greater chance of AEM, and thus are limiting their REM activities.

This could be because at low levels of short-term debt, firms can choose between REM and AEM, but REM is more potential due to it being more challenging to uncover. However, at higher levels of short-term debt, higher financial distress risk and liquidity risk could curb the managerial tendency to resort to REM, because this could provide even a clearer signal about the firm's weak financial status.

Therefore, firms can choose AEM instead, leading to an inverted relationship in the form of $U$ between the use of short-term loans and REM. Interestingly, once again, these findings are double-checked when using proxy REM1.

This argues that in real earnings management activities, managers are fond of magnifying sales, making the lower cost of goods sold to get short-run earnings targets. 
Table 3 - Regression results - Model (1)

(Source: Authors' own calculations)

\begin{tabular}{|c|c|c|c|c|c|c|}
\hline & REM1 & REM2 & REM3 & REM1 & REM2 & REM3 \\
\hline & $(1)$ & (2) & (3) & $(4)$ & (5) & $(6)$ \\
\hline STD & $\begin{array}{l}0.023 * * * \\
(0.007)\end{array}$ & $\begin{array}{l}-0.001 \\
(0.005)\end{array}$ & $\begin{array}{l}0.021 \\
(0.011)\end{array}$ & $\begin{array}{l}0.0211^{* *} \\
(0.009)\end{array}$ & $\begin{array}{l}-0.003 \\
(0.006)\end{array}$ & $\begin{array}{c}0.017 \\
(0.014)\end{array}$ \\
\hline AEM & $\begin{array}{c}0.001 \\
(0.121)\end{array}$ & $\begin{array}{c}0.028 \\
(0.032)\end{array}$ & $\begin{array}{c}0.028 \\
(0.151)\end{array}$ & $\begin{array}{l}-0.037 \\
(0.118)\end{array}$ & $\begin{array}{c}0.018 \\
(0.031)\end{array}$ & $\begin{array}{l}-0.021 \\
(0.146)\end{array}$ \\
\hline $\mathrm{STD}^{*} \mathrm{AEM}$ & $\begin{array}{l}0.298 \quad \star \star \star \\
(0.112)\end{array}$ & $\begin{array}{c}0.008 \\
(0.034)\end{array}$ & $\begin{array}{l}0.306 \text { ** } \\
(0.139)\end{array}$ & $\begin{array}{l}0.350 * * * \\
(0.110)\end{array}$ & $\begin{array}{c}0.015 \\
(0.033)\end{array}$ & $\begin{array}{l}0.369 * * * \\
(0.137)\end{array}$ \\
\hline SIZE & $\begin{array}{l}0.007 * * * \\
(0.002)\end{array}$ & $\begin{array}{l}0.004 * * * \\
(0.001)\end{array}$ & $\begin{array}{l}0.010 * \star \star \\
(0.003)\end{array}$ & $\begin{array}{l}0.007 \\
(0.002)\end{array}$ & $\begin{array}{l}0.004 \quad * * * \\
(0.001)\end{array}$ & $\begin{array}{l}0.011 \\
(0.003)\end{array}$ \\
\hline $\mathrm{ROA}$ & $\begin{array}{l}-0.869 * \star \star \\
(0.050)\end{array}$ & $\begin{array}{l}-0.196 * * * \\
(0.032)\end{array}$ & $\begin{array}{l}-1.066 * \star \star \\
(0.078)\end{array}$ & $\begin{array}{l}-0.895 * * * \\
(0.052)\end{array}$ & $\begin{array}{l}-0.185 * \star * \\
(0.032)\end{array}$ & $\begin{array}{l}-1.081 \quad * * * \\
(0.080)\end{array}$ \\
\hline GROW & $\begin{array}{c}0.002 \\
(0.002)\end{array}$ & $\begin{array}{l}-0.002 \quad * * \\
(0.001)\end{array}$ & $\begin{array}{c}0.000 \\
(0.001)\end{array}$ & $\begin{array}{l}0.012 \text { (0.0** } \\
(0.003)\end{array}$ & $\begin{array}{l}-0.001 \\
(0.002)\end{array}$ & $\begin{array}{l}0.010 * * * \\
(0.003)\end{array}$ \\
\hline $\mathrm{CASH}$ & $\begin{array}{l}-0.048 * \star \\
(0.021)\end{array}$ & $\begin{array}{l}-0.050 \star \star \star \star \\
(0.014)\end{array}$ & $\begin{array}{l}-0.101 \\
(0.032)\end{array}$ & $\begin{array}{l}-0.045 * \star \\
(0.022)\end{array}$ & $\begin{array}{l}-0.053 * * * \\
(0.015)\end{array}$ & $\begin{array}{l}-0.100 * \star * \\
(0.034)\end{array}$ \\
\hline BIG4 & $\begin{array}{l}-0.022 * * * \\
(0.007)\end{array}$ & $\begin{array}{l}-0.016 * * * \\
(0.005)\end{array}$ & $\begin{array}{l}-0.037 * * * \\
(0.011)\end{array}$ & $\begin{array}{l}-0.022 * * * \\
(0.007)\end{array}$ & $\begin{array}{l}-0.016 * * * \\
(0.005)\end{array}$ & $\begin{array}{l}-0.037 * * * \\
(0.011)\end{array}$ \\
\hline IND 4 & $\begin{array}{l}-0.020 * * * \\
(0.008)\end{array}$ & $\begin{array}{l}-0.011 \star \star \star \\
(0.005)\end{array}$ & $\begin{array}{l}-0.030 * \star * \\
(0.011)\end{array}$ & $\begin{array}{l}-0.024 \star \star \star \star \\
(0.008)\end{array}$ & $\begin{array}{l}-0.013 * \star * \\
(0.005)\end{array}$ & $\begin{array}{l}-0.037 * \star * \\
(0.012)\end{array}$ \\
\hline IND7 & $\begin{array}{l}-0.022 \star \star * \\
(0.009)\end{array}$ & $\begin{array}{l}-0.006 \\
(0.008)\end{array}$ & $\begin{array}{l}-0.027 \star \\
(0.015)\end{array}$ & $\begin{array}{l}-0.024 * \star \\
(0.010)\end{array}$ & $\begin{array}{l}-0.007 \\
(0.008)\end{array}$ & $\begin{array}{l}-0.030 * \\
(0.015)\end{array}$ \\
\hline _cons & $\begin{array}{l}-0.130 * \star \star \\
(0.049)\end{array}$ & $\begin{array}{l}-0.078 \star \star \star \\
(0.031)\end{array}$ & $\begin{array}{l}-0.211 * * * \\
(0.072)\end{array}$ & $\begin{array}{l}-0.139 * * * \\
(0.050)\end{array}$ & $\begin{array}{l}-0.078 * \star \\
(0.033)\end{array}$ & $\begin{array}{l}-0.218 * * * \\
(0.076)\end{array}$ \\
\hline $\mathrm{N}$ & 3670 & 3703 & 3670 & 3547 & 3575 & 3547 \\
\hline
\end{tabular}
are standard errors.

Table 4 - Regression results - Model (2)

(Source: Authors' own calculations)

\begin{tabular}{|c|c|c|c|c|c|c|}
\hline & REM1 & REM2 & REM3 & REM1 & REM2 & REM3 \\
\hline & (1) & (2) & (3) & $(4)$ & (5) & (6) \\
\hline STD & $\begin{array}{l}0.077 * * \\
(0.032)\end{array}$ & $\begin{array}{l}0.019 \\
(0.021)\end{array}$ & $\begin{array}{l}0.098 \text { ** } \\
(0.048)\end{array}$ & $\begin{array}{l}0.111 \\
(0.052)\end{array}$ ** & 0.016 & 0.132 * \\
\hline STD2 & $\begin{array}{l}-0.048 * \\
(0.028)\end{array}$ & $\begin{array}{l}-0.017 \\
(0.018)\end{array}$ & $\begin{array}{l}-0.067 \\
(0.041)\end{array}$ & $\begin{array}{l}-0.078 \text { * } \\
(0.044)\end{array}$ & $\begin{array}{l}-0.017 \\
(0.029)\end{array}$ & $\begin{array}{l}-0.100 \\
(0.067)\end{array}$ \\
\hline AEM & $\begin{array}{l}0.214 * * * \\
(0.064)\end{array}$ & $\begin{array}{l}0.034 \\
(0.014)\end{array}$ & $\begin{array}{l}0.247 * * * \\
(0.077)\end{array}$ & $\begin{array}{l}0.212 * * * \\
(0.066)\end{array}$ & $\begin{array}{l}0.030 \text { ** } \\
(0.014)\end{array}$ & $\begin{array}{l}0.242 \quad * * * \\
(0.078)\end{array}$ \\
\hline SIZE & $\begin{array}{l}0.006 * * * \\
(0.002)\end{array}$ & $\begin{array}{l}0.004 * \star \star \\
(0.001)\end{array}$ & $\begin{array}{l}0.010 * * * \\
(0.003)\end{array}$ & $\begin{array}{l}0.006 * \star \star \\
(0.002)\end{array}$ & $\begin{array}{l}0.004 \quad * * * \\
(0.001)\end{array}$ & $\begin{array}{l}0.010 * * * \\
(0.003)\end{array}$ \\
\hline $\mathrm{ROA}$ & $\begin{array}{l}-0.849 * * * \\
(0.052)\end{array}$ & $\begin{array}{l}-0.195 * * * \\
(0.032)\end{array}$ & $\begin{array}{l}-1.045 * * * \\
(0.078)\end{array}$ & $\begin{array}{l}-0.872 \star * * * \\
(0.054)\end{array}$ & $\begin{array}{l}-0.184 \quad * * * \\
(0.032)\end{array}$ & $\begin{array}{l}-1.056 * * * \\
(0.081)\end{array}$ \\
\hline GROW & $\begin{array}{c}0.002 \\
(0.002)\end{array}$ & $\begin{array}{l}-0.002 * * \\
(0.001)\end{array}$ & $\begin{array}{c}0.000 \\
(0.001)\end{array}$ & $\begin{array}{l}0.012{ }^{*} \\
(0.003)\end{array}$ & $\begin{array}{l}-0.001 \\
(0.002)\end{array}$ & $\begin{array}{l}0.010 * \star \star \\
(0.003)\end{array}$ \\
\hline $\mathrm{CASH}$ & $\begin{array}{l}-0.052 \\
(0.022)\end{array}$ & $\begin{array}{l}-0.048 * * * \\
(0.014)\end{array}$ & $\begin{array}{l}-0.103 * * * \\
(0.033)\end{array}$ & $\begin{array}{l}-0.048 * * \\
(0.024)\end{array}$ & $\begin{array}{l}-0.051 * * * \\
(0.015)\end{array}$ & $\begin{array}{l}-0.102 \\
(0.036)\end{array}$ \\
\hline BIG 4 & $\begin{array}{l}-0.021 * * * \\
(0.007)\end{array}$ & $\begin{array}{l}-0.016 * \star \star \\
(0.005)\end{array}$ & $\begin{array}{l}-0.036 \star * \star \\
(0.011)\end{array}$ & $\begin{array}{l}-0.021 * * \star \\
(0.007)\end{array}$ & $\begin{array}{l}-0.016 * \star \star \\
(0.005)\end{array}$ & $\begin{array}{l}-0.036 * \star * \\
(0.011)\end{array}$ \\
\hline IND 4 & $\begin{array}{l}-0.019 \star * \\
(0.007)\end{array}$ & $\begin{array}{l}-0.010 * * \\
(0.005)\end{array}$ & $\begin{array}{l}-0.029 * * * \\
(0.011)\end{array}$ & $\begin{array}{l}-0.022 \star * \star * \\
(0.008)\end{array}$ & $\begin{array}{l}-0.013 * \star * \\
(0.005)\end{array}$ & $\begin{array}{l}-0.034 \quad * * * \\
(0.012)\end{array}$ \\
\hline IND7 & $\begin{array}{l}-0.021 \quad * * \\
(0.010)\end{array}$ & $\begin{array}{l}-0.005 \\
(0.008)\end{array}$ & $\begin{array}{l}-0.026 \star \\
(0.015)\end{array}$ & $\begin{array}{l}-0.022 \star \star \star \\
(0.010)\end{array}$ & $\begin{array}{l}-0.006 \\
(0.008)\end{array}$ & $\begin{array}{l}-0.028 \star \\
(0.016)\end{array}$ \\
\hline _cons & $\begin{array}{l}-0.122 \quad * * \\
(0.049)\end{array}$ & $\begin{array}{l}-0.077 \text { ** } \\
(0.031)\end{array}$ & $\begin{array}{l}-0.202 \quad * * * \\
(0.073)\end{array}$ & $\begin{array}{l}-0.130 * * \\
(0.051)\end{array}$ & $\begin{array}{l}-0.078 \text { ** } \\
(0.033)\end{array}$ & $\begin{array}{l}-0.207 \quad * * * \\
(0.076)\end{array}$ \\
\hline $\mathrm{N}$ & 3670 & 3703 & 3670 & 3547 & 3575 & 3547 \\
\hline
\end{tabular}

$*, * *, * * *$ denote statistical significance at $10 \%, 5 \%$ and $1 \%$, respectively. Numbers in parentheses are standard errors. 


\section{SHORT-TERM DEBT AND FIRMS' EARNINGS}

Finally, the results for other control variables are very similar to those in the previous findings: SIZE is influenced positively by real earnings management variables, in compliance with the agency theory and the positive accounting theory. Both ROA and CASH's coefficients are negative and significant, confirming that REM is more likely to take place in businesses with more financial difficulties. GROW is linked positively to real earnings management variables, and this may be because increasing sales is one type of real manipulation method. BIG4 is negative and significant, as it would be consistent with prior research which showed that the low degree of REM is usually reported by the clients of Big4 auditors. Industry dummies, including IND4 and IND7, are positively affected by real earnings management variables, implying that litigation-prone industry firms tend to perform less real earnings management.

\section{Robustness tests}

For robustness checking, we use two short-term debt-based regression modules to reexamine the short-term debt and REM-related relationships, at low- and high-short-term debt levels. The columns with (L) suggest that short-term debt companies are regressed below the median of the distribution of short-term debt while columns with $(\mathrm{H})$ report the regressing companies that have median short-term debt (Table 5). We also control for the endogeneity with the two above sub-samples to ascertain our findings (Table 6).

Table 5 - Regression results - below and over median of the short-term debt distribution (Source: Authors' own calculations)

\begin{tabular}{|c|c|c|c|c|c|c|}
\hline & REM1-H & REM1-L & REM2-H & REM2-L & REM3-H & REM3-L \\
\hline STD & $\begin{array}{c}0.046 \\
(0.097)\end{array}$ & $\begin{array}{l}0.031)^{* * *} \\
(0.012)\end{array}$ & $\begin{array}{l}-0.046 \\
(0.059)\end{array}$ & $\begin{array}{l}-0.001 \\
(0.007)\end{array}$ & $\begin{array}{l}-0.007 \\
(0.136)\end{array}$ & $\begin{array}{c}0.031 \\
(0.017)\end{array}$ \\
\hline AEM & $\begin{array}{l}0.315 * * * \\
(0.035)\end{array}$ & $\begin{array}{l}0.138 * \\
(0.072)\end{array}$ & $\begin{array}{l}0.048 * * * \\
(0.014)\end{array}$ & $\begin{array}{c}0.024 \\
(0.019)\end{array}$ & $\begin{array}{l}0.363 * * * \\
(0.044)\end{array}$ & $\begin{array}{l}0.160 * \\
(0.089)\end{array}$ \\
\hline SIZE & $\begin{array}{l}0.008 * \star \star \\
(0.003)\end{array}$ & $\begin{array}{l}0.006 * * \star \\
(0.002)\end{array}$ & $\begin{array}{l}0.004 * \star \\
(0.002)\end{array}$ & $\begin{array}{l}0.004 * \star \star \\
(0.001)\end{array}$ & $\begin{array}{l}0.012{ }^{0.01 *} \\
(0.004)\end{array}$ & $\begin{array}{l}0.009 * \star * \\
(0.003)\end{array}$ \\
\hline $\mathrm{ROA}$ & $\begin{array}{l}-0.919 * \star \star \\
(0.060)\end{array}$ & $\begin{array}{l}-0.821 * * * \\
(0.079)\end{array}$ & $\begin{array}{l}-0.256 * \star \star \\
(0.041)\end{array}$ & $\begin{array}{l}-0.131 \quad * * * \\
(0.048)\end{array}$ & $\begin{array}{l}-1.177 \quad * \star * \\
(0.094)\end{array}$ & $\begin{array}{l}-0.953 * * * \\
(0.121)\end{array}$ \\
\hline GROW & $\begin{array}{c}0.001 \\
(0.001)\end{array}$ & $\begin{array}{l}0.004 \\
(0.003)\end{array}$ & $\begin{array}{l}-0.001 \\
(0.001)\end{array} *$ & $\begin{array}{l}-0.004 \quad \star \star \star \\
(0.001)\end{array}$ & $\begin{array}{c}0.000 \\
(0.002)\end{array}$ & $\begin{array}{c}0.000 \\
(0.002)\end{array}$ \\
\hline $\mathrm{CASH}$ & $\begin{array}{l}-0.062{ }^{2} \\
(0.030)\end{array}$ & $\begin{array}{l}-0.023 \\
(0.030)\end{array}$ & $\begin{array}{l}-0.045 * * \\
(0.021)\end{array}$ & $\begin{array}{l}-0.051 \\
(0.018)\end{array}$ & $\begin{array}{l}-0.111 * * \\
(0.047)\end{array}$ & $\begin{array}{l}-0.072 * \\
(0.043)\end{array}$ \\
\hline BIG4 & $\begin{array}{l}-0.036 * \star \star \\
(0.011)\end{array}$ & $\begin{array}{l}-0.008 \\
(0.008)\end{array}$ & $\begin{array}{l}-0.026 * \star * \\
(0.008)\end{array}$ & $\begin{array}{l}-0.006 \\
(0.005)\end{array}$ & $\begin{array}{l}-0.062 * \star \star \\
(0.017)\end{array}$ & $\begin{array}{l}-0.015 \\
(0.012)\end{array}$ \\
\hline IND4 & $\begin{array}{l}-0.018 \\
(0.016)\end{array}$ & $\begin{array}{l}-0.019 * * \\
(0.008)\end{array}$ & $\begin{array}{l}-0.033 * * * \\
(0.009)\end{array}$ & $\begin{array}{c}0.002 \\
(0.005)\end{array}$ & $\begin{array}{l}-0.051 \star * \star \\
(0.023)\end{array}$ & $\begin{array}{l}-0.016 \\
(0.012)\end{array}$ \\
\hline $\begin{array}{l}\text { IND7 } \\
\text { _cons }\end{array}$ & $\begin{array}{l}-0.017 \\
(0.011) \\
-0.173 \\
(0.128) \\
\end{array}$ & $\begin{array}{l}-0.045 * * * \\
(0.013) \\
-0.112 \star \\
(0.060)\end{array}$ & $\begin{array}{l}-0.009 \\
(0.010) \\
-0.034 \\
(0.087) \\
\end{array}$ & $\begin{array}{l}-0.002 \\
(0.009) \\
-0.079 \\
(0.039)\end{array}$ & $\begin{array}{l}-0.025 \\
(0.018) \\
-0.202 \\
(0.190) \\
\end{array}$ & $\begin{array}{l}-0.047 \star * \star \\
(0.020) \\
-0.196 \star \star \\
(0.091)\end{array}$ \\
\hline $\mathrm{N}$ & 1865 & 1805 & 1881 & 1822 & 1865 & 1805 \\
\hline
\end{tabular}

From Table 5, positive coefficients of STD (the coefficient is $0.031>0$ in both REM1 and REM3 models) confirm that REM is linked to short-term debt positively only when shortterm debt is used at the lower level. This is again consistent with H2. Interestingly, AEM is linked to REM in a positive way only when short-term debt is used at high levels. This evidence provides a robust base to support our argument: firms prefer to choose REM if 
short-term debt levels are low. However, at higher levels, firms are bound to utilize AEM instead, leading to a reduction in REM. These results are highly consistent with those in Table 4.

Table 6: Regression results - below and over median of short-term debt distribution after controlling for endogeneity

(Source: Authors' own calculations)

\begin{tabular}{|c|c|c|c|c|c|c|}
\hline & REM1-H & REM1-L & REM2-H & REM2-L & REM3-H & REM3-L \\
\hline STD & $\begin{array}{c}0.197 \\
(0.462)\end{array}$ & $\begin{array}{c}0.025 \\
(0.018)\end{array}$ & $\begin{array}{l}0.570 \text { * } \\
(0.331)\end{array}$ & $\begin{array}{l}-0.018 \\
(0.011)\end{array}$ & $\begin{array}{c}0.735 \\
(0.698)\end{array}$ & $\begin{array}{c}0.008 \\
(0.026)\end{array}$ \\
\hline AEM & $\begin{array}{l}0.328 * * * \\
(0.037)\end{array}$ & $\begin{array}{l}0.128 \text { * } \\
(0.068)\end{array}$ & $\begin{array}{l}0.043 * \star \star \\
(0.014)\end{array}$ & $\begin{array}{c}0.020 \\
(0.018)\end{array}$ & $\begin{array}{l}0.372 \\
(0.045)\end{array}$ & $\begin{array}{l}0.148 * \\
(0.084)\end{array}$ \\
\hline SIZE & $\begin{array}{l}0.009 * * \\
(0.004)\end{array}$ & $\begin{array}{l}0.006 * * * \\
(0.002)\end{array}$ & $\begin{array}{l}0.008 * * * \\
(0.003)\end{array}$ & $\begin{array}{l}0.003 \\
(0.001)\end{array}$ & $\begin{array}{l}0.017 * \star \star \\
(0.006)\end{array}$ & $\begin{array}{l}0.009 * * * \\
(0.003)\end{array}$ \\
\hline $\mathrm{ROA}$ & $\begin{array}{l}-0.977 * \star \star \\
(0.063)\end{array}$ & $\begin{array}{l}-0.825 * \star \star \\
(0.081)\end{array}$ & $\begin{array}{l}-0.278 * \star \star \\
(0.043)\end{array}$ & $\begin{array}{l}-0.121{ }^{*} \\
(0.049)\end{array}$ & $\begin{array}{l}-1.255 * \star \star \\
(0.096)\end{array}$ & $\begin{array}{l}-0.945 * \star * \\
(0.124)\end{array}$ \\
\hline GROW & $\begin{array}{l}0.013 * * * \\
(0.003)\end{array}$ & $\begin{array}{l}0.011 \\
(0.006)\end{array}$ & $\begin{array}{c}0.001 \\
(0.003)\end{array}$ & $\begin{array}{l}-0.004 * \star \\
(0.002)\end{array}$ & $\begin{array}{l}0.014 * * * \\
(0.004)\end{array}$ & $\begin{array}{c}0.005 \\
(0.006)\end{array}$ \\
\hline $\mathrm{CASH}$ & $\begin{array}{l}-0.066 * \\
(0.038)\end{array}$ & $\begin{array}{l}-0.023 \\
(0.032)\end{array}$ & $\begin{array}{l}-0.078 \quad * \star * \\
(0.028)\end{array}$ & $\begin{array}{l}-0.058 * \star \star \\
(0.019)\end{array}$ & $\begin{array}{l}-0.148 * \star \\
(0.060)\end{array}$ & $\begin{array}{l}-0.080 \text { * } \\
(0.046)\end{array}$ \\
\hline BIG4 & $\begin{array}{l}-0.038 * * * \\
(0.012)\end{array}$ & $\begin{array}{l}-0.008 \\
(0.008)\end{array}$ & $\begin{array}{l}-0.028 * * * \\
(0.008)\end{array}$ & $\begin{array}{l}-0.006 \\
(0.005)\end{array}$ & $\begin{array}{l}-0.065 * * * \\
(0.018)\end{array}$ & $\begin{array}{l}-0.014 \\
(0.013)\end{array}$ \\
\hline IND 4 & $\begin{array}{l}-0.025 \\
(0.017)\end{array}$ & $\begin{array}{l}-0.021 * \star \\
(0.008)\end{array}$ & $\begin{array}{l}-0.041 \quad * \star * \\
(0.010)\end{array}$ & $\begin{array}{l}-0.002 \\
(0.005)\end{array}$ & $\begin{array}{l}-0.065 * \star * \\
(0.025)\end{array}$ & $\begin{array}{l}-0.023 * \\
(0.012)\end{array}$ \\
\hline IND7 & $\begin{array}{l}-0.020 \\
(0.012)\end{array}$ & $\begin{array}{l}-0.049 * * * \\
(0.014)\end{array}$ & $\begin{array}{l}-0.014 \\
(0.010)\end{array}$ & $\begin{array}{l}-0.004 \\
(0.009)\end{array}$ & $\begin{array}{l}-0.033 * \\
(0.019)\end{array}$ & $\begin{array}{l}-0.052 \\
(0.020)\end{array}$ \\
\hline _cons & $\begin{array}{l}-0.356 \\
(0.515)\end{array}$ & $\begin{array}{l}-0.120 * \\
(0.062)\end{array}$ & $\begin{array}{l}-0.743 * \\
(0.381)\end{array}$ & $\begin{array}{l}-0.061 \\
(0.040)\end{array}$ & $\begin{array}{l}-1.062 \\
(0.792)\end{array}$ & $\begin{array}{l}-0.187 * * \\
(0.094)\end{array}$ \\
\hline $\mathrm{N}$ & 1776 & 1771 & 1789 & 1786 & 1776 & 1771 \\
\hline
\end{tabular}

Finally, we basically redo the regression for both samples as in Table 5, but this time with endogeneity being controlled by lagging all the explanatory variables by one period as in Table 6. In Table 6, the results are similar to the ones drawn in Table 5. The nonlinear relationship between short-term debt and REM is therefore confirmed.

\section{Conclusion}

Previous studies indicate a positive outcome of short-term debt on earnings management under financial distress and refinancing pressure. The earlier literature, on the other hand, showed that short-term debt and earnings management are relatively negatively affected by the role of short-term debt monitoring. Furthermore, managers could use two approaches (REM and AEM) to manipulate the earnings. Nonetheless, according to our literature review, there have been no studies to investigate the relationship between AEM and REM at low- and high-short-term debt levels. Examining this relationship should add significantly to the current literature on the choice between REM and AEM, as well as the correlation between the use of short-term loans and earnings management in general.

Based on 5,150 company-year observations in Vietnam for the period 2009-2018, the findings show that, in general, there is a significantly positive association between short-term debt and REM, supporting hypothesis $\mathrm{H} 1$ regarding the financial distress factor. Further examining the nonlinear relationship, we note that companies that have a lower level of 


\section{SHORT-TERM DEBT AND FIRMS' EARNINGS}

short-term debt are likely to take advantage of REM activities, whereas companies with a greater level of short-term debt are converted to AEM which reduces REM activities. Our robustness tests ascertain the presence of an inverted relationship in the form of $U$ between short-term debt and REM.

\section{References:}

1. Ahn, S. \& Choi, W. (2009). The role of bank monitoring in corporate governance: Evidence from borrowers' earnings management behavior. Journal of Banking \& Finance, 33(2), 425434.

2. Andhov, A., Brocková, K. \& Šimalová, K. (2019). Slovakia. In Investment Arbitration in Central and Eastern Europe : Law and Practice. Cheltenham; Northampton: Edward Elgar Publishing.

3. Brusenskaya, L.A., Kulikova, E.G. \& Zolochevskaya E.Y. (2018). Anti-Drug Social Advertising In The Modern Media Space: Persuasiveness And Cognitive Basis. Mediaeducation, 2, 71-78.

4. Dechow, P. M. \& Dichev, I. D. (2002). The quality of accruals and earnings: The role of accrual estimation errors. The accounting review, 77(s-1), 35-59.

5. El Diri, M. (2018). Definitions, activities, and measurement of earnings management. In Introduction to earnings management (5-44). Springer, Cham.

6. Fields, L. P., Gupta, M., Wilkins, M. \& Zhang, S. (2018). Refinancing pressure and earnings management: Evidence from changes in short-term debt and discretionary accruals. Finance Research Letters, 25, 62-68.

7. Fung, S. Y. K. \& Goodwin, J. (2013). Short-term debt maturity, monitoring and accruals-based earnings management. Journal of Contemporary Accounting \& Economics, 9(1), 67-82.

8. Ghosh, A. \& Moon, D. (2010). Corporate debt financing and earnings quality. Journal of Business, Finance and Accounting, 10, 1-22.

9. Gupta, M., Khurana, I. K., \& Pereira, R. (2008). Legal Enforcement, Short Maturity Debt, and the Incentive to Manage Earnings. The Journal of Law and Economics, 51(4), 619-639.

10. Huang, X., \& Sun, L. (2017). Managerial ability and real earnings management. Advances in Accounting, 39, 91-104.

11. Jančíková, E., Raneta, L. \& Braga, D. (2016). Internationalization of renminbi and the real effective exchange rate. Journal for economic theory, economic policy, social and economic forecasting, 64(7), 666-685.

12. McNichols, M. F. (2002). Discussion of the quality of accruals and earnings: The role of accrual estimation errors. The accounting review, 77(s-1), 61-69.

13. Myers, S. (1977). Determinants of corporate borrowing. Journal of Financial Economics, 5, 146-175.

14. Popova, E.A., Zolochevskaya, E.Yu. \& Morozova, A.I. (2018). Science Collaboration As A Modern Institution For Developing State Management Of Intellectual Capital In Russia. $C B U$ International Conference Proceedings, 405-410.

15. Rey, P., and Stiglitz, J. E., (1993). Short-term Contracts as a Monitoring Device. National Bureau of Economic Research, Working Paper, NBER 4514. 
16. Roychowdhury, S. (2006). Earnings management through real activities manipulation. Journal of Accounting and Economics, 42(3), 335-370.

17. Zang, A. Y. (2012). Evidence on the trade-off between real activities manipulation and accrualbased earnings management. The Accounting Review, 87(2), 675-703.

Paper submitted

Paper accepted for publishing

Paper published online
28 November 2020

02 March 2021

31 March 2021 